\title{
PENGARUH PERSEPSI KEMUDAHAN BERBELANJA, REPUTASI WEBSITE, DAN KUALITAS WEBSITE TERHADAP MINAT BELI ONLINE: KEPERCAYAAN SEBAGAI VARIABEL MEDIASI
}

\author{
Wiendy Deborah \\ Program Studi Magister Manajemen Universitas Tarumanagara \\ wiendy.117171055@stu.untar.ac.id \\ Keni \\ Program Studi Magister Manajemen Universitas Tarumanagara
}

\begin{abstract}
This study aims to determine the main factors that can influence the purchase intention from consumers. Based on previous research, three independent variables were obtained: perceptions of ease to use, website reputation, website quality and one intervening variable; trust that can attract purchase intention. This is a descriptive research by using questionnaire which distributed to 164 respondents in Jakarta area. Data was collected by using non probability sampling method. Regression analysis were used for data analysis by using SPSS. From this study, it was found that the influence of each variables can directly and indirectly influence purchase intention significantly.
\end{abstract}

Abstrak : Penelitian ini bertujuan untuk mengetahui faktor utama yang dapat mempengaruhi minat beli online dari konsumen. Berdasarkan penelitian terdahulu, didapatkan tiga variabel independen, yaitu: persepsi kemudahan berbelanja, reputasi website, kualitas website dan satu variabel mediasi, yaitu: kepercayaan yang dapat menarik minat beli konsumen. Jenis penilitian yang digunakan adalah penilitian deskriptif, dengan menggunakan sejumlah 164 kuesioner yang tersebar terhadap responden di Jakarta. Pengambilan data dilakukan dengan metode non probability sampling. Analisis data menggunakan analisis regresi yang diolah dengan program SPSS. Berdasarkan hasil penelitian didapatkan bahwa pengaruh masingmasing variabel secara langsung maupun tidak langsung dapat mempengaruhi minat beli online secara signifikan.

Keywords : Purchase intention, ease of use, website reputation, website quality, and trust

\section{PENDAHULUAN}

Pertumbuhan industri e-commerce di Indonesia saat ini semakin pesat mengikuti perkembangan jaman teknologi. Namun walaupun pertumbuhan e-commerce meningkat pesat, kompetisi pasar kini tetap semakin ketat karena banyaknya pesaing dalam industri ini. Ketatnya persaingan pasar di Indonesia, membuat setiap perusahaan e-commerce perlu meningkatkan minat beli dari konsumen agar dapat meningkatkan penjualan juga, sehingga perusahaan dirasakan perlu meneliti faktor-faktor yang dapat meningkatkan minat beli online.

Menurut Faradila dan Soesanto (2016) faktor yang dapat mempengaruhi minat beli ialah persepsi kemudahan dan persespi manfaat secara langsung ataupun melalui kepercayaan sebagai mediasi. Di mana didapatkan bahwa faktor pesepsi kemudahan melalui mediasi kepercayaan dengan indikatornya adalah kemudahan mempelajari website, kemudahan mencari produk yang sesuai dengan kebutuhan, dan kemudahan menggunakan website dengan terampil dan tanpa kesulitan merupakan faktor yang paling mempengaruhi minat beli.

Akroush dan Debei (2015) dalam penelitiannya juga mengungkapkan bahwa reputasi memiliki hubungan yang bersifat positif dengan kepercayaan. Semakin baik reputasi suatu perusahaan juga akan semakin tinggi kepercayaan konsumen yang pada akhirnya juga akan berdapak positif terhadap sikap belanja online. 
Kualitas website adalah salah satu faktor yang sangat perlu diperhatikan oleh semua pihak yang melakukan proses penjualan secara online. Bavarsad et al. (2013) menjelaskan bahwa website yang baik memiliki kualitas operasional yang memungkinkan pembeli untuk melakukan aktivitas e-shopping mereka dengan mudah dan efisiensi

Faradila dan Soesanto (2016) mengatakan bahwa rasa percaya berpengaruh terhadap minat beli dengan indikatornya adalah website dapat dipercaya, website dikenal sebagai situs yang dapat memenuhi janjinya, dan tidak ada alasan untuk khawatir saat menggunakan website. Oleh karena itu, terdapat beberapa hal yang harus diperhatikan saat membentuk sebuah website toko online agar dapat memperoleh kepercayaan dari pengguna website.

Selain menjadi faktor yang mempengaruhi secara langsung terhadap minat beli, kepercayaan dapat menjadi variabel mediasi. Adapun penelitian terdahulu mendapatkan faktor persepsi kemudahan berbelanja berdasarkan Faradila dan Soesanto (2016) dan faktor reputasi serta kualitas website berdasarkan Shahnaz dan Wahyono (2016) terhadap minat beli online dengan kepercayaan sebagai variabel mediasi berpengaruh signifikan, sehingga dapat disimpulkan bahwa kepercayaan dapat menjadi mediasi yang baik antar faktor tersebut terhadap minat beli online.

\section{TELAAH KEPUSTAKAAN Minat Beli}

Younus et al. (2015:2) mendefinisikan minat beli sebagai "the preference of consumer to buy the product or service. Jadi dapat disumpulkan minat beli ialah kecendrungan responden setelah menerima ranggsangan dari produk yang dilihat yang dapat menimbulkan keinginan sebelum keputusan pembelian dilaksanakan.

\section{Kemudahan Berbelanja}

Menurut Davis (1989:320), Kemudahan (perceived ease of use) didefinisikan sebagai "the degree to which a person believes that using a particular system would be free of effort". Penelitian ini menggunakan konsep definisi dari Davis (1998), yang dapat diartikan bahwa suatu derajat dimana seseorang percaya bahwa dengan menggunakan sebuah teknologi akan membuat seseorang bebas dari upaya

\section{Reputasi Website}

Menurut Fombrun (1996) dalam Hardjana (2008:12), "Reputation is a source of competitive advantage. ... In companies where reputation is valued, managers take great pains to build, sustain, and defend that reputation by following practices that (1) shape a unique identity and (2) project coherent and consistent set of images to the public" Penelitian ini menggunakan konsep definisi dari Fombrun (1996), yang dapat diartikan bahwa reputasi merupakan sumber keunggulan kompetitif perusahaan.

\section{Kualitas Website}

Kualitas website menurut Slabey (1990) dalam Barnes dan Vidgen (2003:298) adalah "Structured and disciplined process that provides a means to identify and carry the voice of the customer through each stage of product and or service development and implementation". Konsep definisi kualitas website menurut Slabey tersebut dapat diartikan; suatu proses terstruktur yang menyediakan sarana untuk mengidentifikasi dan membawa suara pelanggan melalui setiap tahap produk dan ataupun pengembangan dan implementasi layanan.

\section{Kepercayaan}

Mayer et al. (1995:712) mendefinisikan kepercayaan sebagai "the willingness of a party to be vulnerable to the actions of another party based on the expectation that the other will perform a particular action important to the trustor, irrespective, of the ability to monitor or control that other party." Konsep definisi kepercayaan menurut Mayer, et al (1995), tersebut dapat diartikan sebagai suatu keinginan seseorang untuk peka terhadap tindakan orang lain berdasarkan harapan dimana orang lain akan melakukan tindakan tertentu 
pada orang yang dipercayainya, tanpa tergantung pada kemampuannya dalam mengawasi dan mengendalikannya.

\section{Kaitan antar Variabel}

- Pengaruh Persepsi Kemudahan Berbelanja, Reputasi Website, dan Kualitas Website terhadap Minat Beli

Faradilla dan Soesanto (2016) serta Lau et al. (2016) menemukan bahwa kemudahan penggunaan memiliki pengaruh yang posisitif dan signifikan terhadap minat beli, karena konsumen akan cenderung lebih tertarik membeli barang yang terbukti mudah digunakan. Muda et al. (2016) menemukan bahwa perceived reputation memiliki pengaruh yang positif dan signifikan terhadap purchase intention dan berpendapat bahwa potensial konsumen dapat melihat komentar dari pembeli sebelumnya yang dapat mencerminkan reputasi sebelum membuat keputusan untuk membeli. Berdasarkan penelitian Prihandana dan Natakusuma (2012) didapatkan juga bahwa kualitas website dapat mempengaruhi minat beli konsumen secara signifikan. Perusahaan pun dituntut juga membuat konsumen berpikir bahwa apa yang mereka butuhkan dalam website tersebut sesuai ekspetasi mereka.

Berdasarkan uraian tersebut, hipotesis penelitian (H1) adalah:

H1 : $\quad$ Terdapat pengaruh positif antara (a) persepsi kemudahan berbelanja, (b) reputasi website, dan (c) kualitas website terhadap minat beli

- Pengaruh Persepsi Kemudahan Berbelanja, Reputasi Website, dan Kualitas Website terhadap Kepercayaan

Faradilla dan Soesanto (2016) serta Trisnawati dkk. (2012) mendapatkan bahwa kemudahan pengunaan berpengaruh positif dan signifikan terhadap kepercayaan. Hal ini terjadi, karena mereka akan mempercayai jika situs tersebut mudah dipahami. Akroush dan Debei (2015) juga mendapatkan bahwa website reputation berpengaruh positif dan signifian terhadap trust. Dikatakan bahwa untuk membangun kepercayaan para penjual perlu memperhatikan reputasi mereka. Shahnaz dan Wahyono (2016) menemukan bahwa kualitas website memiliki pengaruh yang signifikan dan positif terhadap kepercayaan. Kualitas website dapat memberikan tampilan dari toko online seperti halnya pada toko offline.

Berdasarkan uraian tersebut, hipotesis penelitian (H2) adalah:

H2 : Terdapat pengaruh positif antara (a) persepsi kemudahan berbelanja, (b) reputasi website, dan (c) kualitas website terhadap kepercayaan

- Pengaruh Kepercayaan terhadap Minat Beli

Muda et al. (2016) dan Trisnawati dkk. (2012) menemukan bahwa trust memiliki pengaruh yang positif dan signifikan terhadap purchase intention. Trisnawati dkk. (2012) mengungkapkan bahwa kepercayaan berpengaruh terhadap repurchase intention, jika konsumen sudah merasa bahwa situs web bisa dipercaya, sehingga berniat membeli kembali.

Berdasarkan uraian tersebut, hipotesis penelitian (H3) adalah:

H3 : $\quad$ Terdapat pengaruh positif antara kepercayaan terhadap minat beli

- Pengaruh Persepsi Kemudahan Berbelanja, Reputasi Website, dan Kualitas Website terhadap Minat Beli melalui Kepercayaan sebagai Mediasi

Li et al. (2007), menemukan bahwa kemudahan penggunaan juga dapat mempengaruhi minat beli melalui kepercayaan. Ketika konsumen memandang bahwa website dapat menjadi tempat berbelanja yang memberikan rasa kemudahan melalui, mereka akan mempercayai website tersebut, sehingga tertarik untuk membeli melalui website tersebut. Shahnaz dan Wahyono (2016) menemukan bahwa reputasi memiliki pengaruh yang signifikan terhadap minat beli melalui kepercayaan sebagai mediasi. Suatu perusahaan dikatakan memiliki reputasi yang baik karena telah memberikan 
produk ataupun layanan yang berkualitas sesuai harapan konsumen, sehingga dapat meningkatkan kepercayaan konsumen yang nantinya berakibat pada minat beli konsumen. Kuo et al. (2014) dan Shahnaz dan Wahyono (2016) juga mendapatkan bahwa website quality memiliki pengaruh yang signifikan terhadap customer purchase intention melalui tust. Hal tersebut terjadi karena website toko online yang berkualitas dapat meningkatkan rasa percaya konsumen terhadap toko online sehingga dapat menimbulkan minat beli konsumen.

Berdasarkan uraian tersebut, hipotesis penelitian (H4) adalah:

H4 : $\quad$ Terdapat pengaruh positif antara (a) persepsi kemudahan berbelanja, (b) reputasi website, dan (c) kualitas website terhadap minat beli melalui kepercayan.

\section{METODOLOGI PENELITIAN}

Populasi dalam penelitian adalah seluruh konsumen e-commerce. Ukuran sampel yang digunakan dalam penelitian ini adalah minimum sebanyak 145 orang. Dalam pengambilan sampel, metode yang digunakan adalah non probability sampling dengan teknik convenience sampling. Skala pengukuran (kecuali profil responden) diukur dengan skala likert 1-5. Dalam tabel 1 menunjukkan instrumen masing-masing variabel beserta sumbernya.

Tabel 1. Variabel dan Pengukuran

\begin{tabular}{|l|c|c|}
\hline \multicolumn{1}{|c|}{ Variabel } & Item & Sumber \\
\hline Variabel independen: & & Trisnawati dkk. (2012) \\
Kemudahan berbelanja & 3 & Kim dan Lennon (2013) \\
Reputasi website & 3 & Napitulu (2016) \\
Kuaitas website & 16 & Akroush and Debei (2015) \\
\hline Variabel mediasi: Kepercayan & 4 & Kim dan Lennon (2013) \\
\hline Variabel dependen:Minat beli online & 3 & \\
\hline
\end{tabular}

Analisis regresi digunakan untuk mengetahui pengaruh masing-masing variabel independen terhadap variabel dependen. Selanjutnya, uji sobel digunakan untuk mengetahui pengaruh masing-masing variabel independen terhadap variabel dependen melaui mediasi. Sebelumnya, dilakukan terlebih dahulu uji validitas, reliabilitas, dan uji asumsi klasik.

\section{HASIL PENELITIAN DAN PEMBAHASAN}

Berdasarkan pengumpulan data terkumpul 164 responden, dan diketahui bahwa mayoritas responden adalah wanita (61,59\%), berumur di 23-29 tahun (85,37\%), tingkat pendidikan S1 (87,80\%), tingkat pengeluaran per bulan Rp 2-5 juta (57,93\%), dan jenis produk yang paling banyak dibeli adalah fashion $(22,14 \%)$

Hasil uji validitas menunjukkan bahwa nilai corrected item total correlation semua butir pernyataan pada setiap variabel penelitian lebih besar dari $r$ tabel yang ditetapkan, yaitu 0,153 , sehingga semua pernyataan pada variabel dalam penelitian ini valid. Sementara hasil dari pengujian reliabilitas seluruh variabel pada penelitian ini diperoleh nilai Cronbach Alpha setiap variabel $>0,6$, maka disimpulkan bahwa seluruh variabel dalam penelitian ini reliabel.

\section{Pengujian Hipotesis}

Tabel 2 menunjukkan pengaruh tiap variabel independen terhadap variabel dependen dan diperoleh hasil bahwa nilai signifikansi setiap variabel $<0,05$, sehingga dapat disimpulkan bahwa keseluruhan hipotesis 1, 2, dan 3 didukung. Selain itu dapat dilihat dari tabel bahwa faktor yang terbesar yang mempengaruhi minat beli online dan kepercayaan adalah kualitas website. 
Tabel 2. Hasil Analisis Regresi

\begin{tabular}{|l|l|c|c|c|}
\hline \multicolumn{2}{|c|}{ Hipotesis } & Koefisien & Sig. & Hasil \\
\hline $\mathrm{H}_{1 \mathrm{a}}$ & Persepsi kemudahan berbelanja $\rightarrow$ minat beli online & 0,155 & 0,016 & Didukung \\
\hline $\mathrm{H}_{1 \mathrm{~b}}$ & Reputasi Website $\rightarrow$ minat beli online & 0,223 & 0,005 & Didukung \\
\hline $\mathrm{H}_{1 \mathrm{c}}$ & Kualitas Website $\rightarrow$ minat beli online & 0,528 & 0,000 & Didukung \\
\hline $\mathrm{H}_{2 \mathrm{a}}$ & Persepsi kemudahan berbelanja $\rightarrow$ kepercayaan & 0,125 & 0,038 & Didukung \\
\hline $\mathrm{H}_{2 \mathrm{~b}}$ & Reputasi Website $\rightarrow$ kepercayaan & 0,278 & 0,000 & Didukung \\
\hline $\mathrm{H}_{2 \mathrm{c}}$ & Kualitas Website $\rightarrow$ kepercayaan & 0,487 & 0,000 & Didukung \\
\hline $\mathrm{H}_{3}$ & Kepercayaan $\rightarrow$ minat beli online & 0,619 & 0,000 & Didukung \\
\hline
\end{tabular}

Kemudian untuk mengetahui masing-masing variabel melalui mediasi menggunakan uji sobel. Berdasarkan hasil uji sobel tiap variabel tersebut didapatkan $t_{\text {hitung }}<t_{\text {tabel, }}$ di mana $\mathrm{t}_{\text {tabel }}$ yang ditentukan adalah 1,65443. Sehingga dapat disimpulkan bahwa $\mathrm{H}_{4}$ juga didukung.

Hasil penelitian ini menunjukkan bahwa persepsi kemudahan berbelanja berpengaruh secara signifikan terhadap minat beli online, yang sejalan dengan penelitiaan terdahulu oleh Faradilla dan Soesanto (2016) serta Lau et al. (2016). Hasil ini menunjukan bahwa belanja online memiliki banyak manfaat tetapi tidak terlepas dari kelemahan yaitu rumitnya media interaksi (website) dalam penggunaannya. Reputasi website berdasarkan hasil penelitian ini didapatkan juga bepengaruh positif dan signifikan terhadap minat beli online. Konsumen akan menilai perusahaan tersebut memiliki reputasi baik, apabila perusahaan tersebut memberikan pelayanan yang baik. Seperti penelitian yang dilakukan oleh Muda et al. (2016) menyatakan bahwa jika tingkat reputasi tinggi, maka minat beli akan tinggi pula. Kualitas website berdasarkan hasil penelitian ini didapatkan juga bepengaruh positif dan signifikan terhadap minat beli, yang sejalan dengan penelitian oleh Prihandana dan Natakusuma (2012). Oleh karena itu setiap atribut dari kualitas website menunjukkan kompetensi dari toko online untuk memberikan layanan terbaik.

Hasil penelitian ini menunjukkan bahwa persepsi kemudahan berbelanja berpengaruh secara signifikan terhadap kepercayaan yang sejalan dengan hasil penelitian terdahulu oleh Trisnawati dkk (2012). serta Faradilla dan Soesanto (2016). Hal tersebut timbul karena apabila konsumen tersebut mengalami kesulitan ketika digunakan oleh konsumen, maka konsumen akan kehilangan kepercayaan terhadap website tersebut. Reputasi website berdasarkan hasil penelitian ini didapatkan juga bepengaruh positif dan signifikan juga terhadap kepercayaan, yang juga sejalan dengan penelitian terdahulu oleh Akroush dan Debei (2015). Reputasi memberikan keyakinan kepada pihak lain dan keyakinan inilah yang akan membantu meningkatkan kepercayaan. Selain itu, kualitas website berdasarkan hasil penelitian ini didapatkan juga bepengaruh positif dan signifikan terhadap kepercayaan, yang seusai dengan penelitian terdahulu oleh Shahnaz dan Wahyono (2016). Hal ini membuktikan bahwa konsumen perlu kualitas website yang baik, dengan memperhatikan keseluruhan atribut.

Hasil penelitian ini menunjukkan bahwa kepercayaan berpengaruh secara signifikan terhadap minat beli online, yang sejalan dengan penelitian terdahulu oleh Muda et al. (2016) dan Trisnawati dkk. (2012). Ketika seorang berbelanja online, salah satu faktor yang pertimbangan dalam membeli adalah apakah mereka percaya kepada website tersebut. Kepercayaan konsumen terhadap suatu website terletak pada terkenal atau tidaknya website tersebut dan kehandalan jasa.

Hasil penelitian ini sejalan dengan yang telah dilakukan oleh Li et al. (2007), yaitu bahwa kemudahan penggunaan dapat mempengaruhi minat beli melalui kepercayaan. Ketika konsumen merasakan kemudahan saat berbelanja, maka juga akan timbul kepercayaan yang dapat meningkatkan minat beli. Hasil penelitian ini juga sejalan dengan hasil penelitian oleh Shahnaz dan Wahyono (2016), yang menemukan bahwa reputasi memiliki pengaruh yang 
signifikan terhadap minat beli melalui kepercayaan sebagai mediasi. Ketertarikan konsumen untuk membeli barang dapat timbul karena memiliki kepercayaan. Kepercayaan ini timbul jika perusahan tersebut memiliki track record yang mencerminkan reputasi. Selain itu hasil penelitian ini menunjukkan bahwa kepercayaan dapat menjadi mediasi antara variabel kualitas website terhadap minat beli online, yang sejalan dengan penelitian terdahulu, Kuo et al. (2014) serta Shahnaz dan Wahyono (2016). Kualitas website dalam penelitian ini pun menjadi faktor yang dapat meningkatkan kepercayaan konsumen. Dengan kualitas website yang terjamin, konsumen akan merasakan pula kepercayaan terhadap perusahaan, yang juga dapat memicu minat beli.

\section{KESIMPULAN DAN SARAN}

Hasil penelitian menunjukkan seluruh hipotesis didukung. Dengan demikian, hasil penelitian juga memberikan saran agar perusahaan senantiasa meningkatkan persepsi kemudahan berbelanja, reputasi website, kualitas website, dapat mempengaruhi minat beli online dalam kegiatan pemasarannya karena terbukti setiap variabel tersebut dapat meningkatkan minat beli online konsumen baik secara langsung maupun melalui kepercayaan sebagai mediasi.

Bagi penelitian selanjutnya, dihimbau untuk mencoba memformulasikan variabel lainnya yang dapat mempengaruhi minat beli, seperti: kualitas jasa, persepsi manfaat, persepsi kenyamanan, persepsi risiko dan juga memperluas cakupan wilayah penelitian.

\section{IMPLIKASI MANAJERIAL}

Berkaitan dengan hasil penelitian, maka dapat disampaikan beberapa implikasi manajerial yang bisa diterapkan oleh perusahaan. Meninjau dari hasil pengaruh positif oleh persepsi kemudahan berbelanja terhadap minat beli online dan kepercayaan, maka dihimbau agar perusahaan tetap konsisten dalam memberikan kemudahan bagi konsumen dalam aspek kemudahan dalam mengunakan situs, berinteraksi, maupun menemukan produk. Untuk variabel reputasi website, dimana perusahaan dihimbau untuk senantiasa menjaga reputasi perusahaan dengan responsibility terhadap konsumen yang dapat meningkatkan nama baik perusahaan, yang dapat meningkatkan kepercayaan dan minat beli onlie. Perusahaan juga dianjurkan untuk tetap meningkatkan kualitas dalam menciptakan pengalaman baik saat konsumen menggunakan jasa dari website tersebut agar tidak timbul kekecewaan. Selain itu untuk variabel kepercayaan, perusahaan dituntut untuk dapat menjaga kepercayaan di mata konsumen, karena terbukti kepercayaan dapat mempengaruhi minat beli dan menjadi mediasi terhadap minat beli. Perusahaan dapat meningkatkan kepercayaan dengan menjaga data konsumen dan menjamin keamanan data pribadi konsumen tersebut tidak untuk disebarkan untuk kepentingan komersil.

\section{DAFTAR PUSTAKA}

Akroush, Mamoun N. dan Mutaz M. Al-Debei. (2015). An integrated model of factors affecting consumer attitudes towards online shopping. Business Process Management Journal, 21 (6), 1353- 1376.

Barnes, S. dan R. Vidgen. (2003). Measuring Web Site Quality Improvements: A Case Study of the Forum on Strategic Management Knowledge Exchange. Industrial Management \& Data Systems, 103(5): 297-309.

Bavarsad, Belghis, Farajollah Rahimi, dan Mohammad Ali Mennatyan. (2013). A Study of the Effects of Website's Perceived Features on the Intention to Use Eshopping. World Applied Programming, 3 (6), 252-263. 
Davis, F.D. (1989). Perceived Usefulness, Perceived Ease of Use and User Acceptance of Information Technology. MIS Quarterly, 13 (3), 319-340.

Faradila, Rr. Selli Nisrina dan Harry Soesanto. (2016). Analisis Pengaruh Persepsi Kemudahan Penggunaan dan Persepsi Manfaat terhadap Minat Beli dengan Kepercayaan Sebagai Variabel Intervening (Studi pada Pengunjung Toko Online berrybenka.com di Kalangan Mahasiswa Universitas Diponegoro). Jurnal Studi Manajemen \& Organisasi, 13, 149-160

Hardjana, Andre A. (2008). Komunikasi dalam Manajemen Reputasi Korporasi. Jurnal Ilmu Komunikasi., 5 (1), 1-24.

Kim, J. dan S. J. Lennon. (2013). Effects of Reputation and Website Quality on Online Consumers Emotion, Perceived Risk and Purchase Intention: Based on the StimulusOrganism-Response Model. Journal of Research in Interactive Marketing, 7 (1), 33 56.

Kuo, Chien Chang, Te Kuo Nien, Lin Hsu Chia, dan Sung Cheng Yi. (2014). The Impact of Website Quality and Perceived Trust on Customer Purchase Intention in the Hotel Sector: Website Brand and Perceived Value as Moderators. International Journal of Innovation, Management and Technology, 5 (4), 255-260.

Lau, Mei Mei dan Aris Y. C. Lam. (2016). Examining the Factors Influencing Purchase Intention of Smartphones in Hong Kong. Contemporary Management Research, 12 (2), 213-224.

Li, R, Jae Jon K. dan Jae Sung P. (2007). The effects of internet shoppers trust on their purchasing intention in China. Journal of Information Systems and Technology Management, 4 (3), 269-286.

Mayer, Roger C., James H. Davis dan F. David Schoorman. (1995). An integrative model of organizational trust. Academy of Management Review, 20 (3), 709-734.

Muda, Mazzini, Rohani Mohd, dan Salwana Hassan. (2016). Online Purchase Behavior of Generation Y in Malaysia. Procedia Economics and Finance, 37, 292-298.

Napitupulu, D. B. (2016). Evaluasi Kualitas Website Universitas XYZ dengan Pendekatan Webqual. Buletin Pos dan Telekomunikasi, 14, 51-64.

Prihandana, Reza dan N, R. M. Yoga Pratama Natakusuma. (2012). Analisa Pengaruh Kualitas Pelayanan dan Kualitas Website terhadap Minat Beli dan Dampaknya terhadap Keputusan Pembelian Konsumen Disdus.com. Jakarta: BINUS University.

Shahnaz, Nanda Bella Fidanty dan Wahyono. (2016). Faktor yang Mempengaruhi Minat Beli Konsumen di Toko Online. Managemant Analysis Journal, 5 (4), 389-399.

Trisnawati, E., A. Suroso, dan U. Kumorohadi. (2012). Analisis Faktor-Faktor Kunci dari Niat Pembelian Kembali secara Online (Studi Kasus pada Konsumen Fesh Shop). Jurnal Bisnis dan Ekonomi, 19 (2), 126-141.

Younus, Sohail, Faiza Rasheed, dan Anas Zia. (2015). Identifying the Factors Affecting Customer Purchase Intention. Global Journal of Management and Business Research: A Administration and Management, 15 (2), 9-13. 
